Discussion

Papers

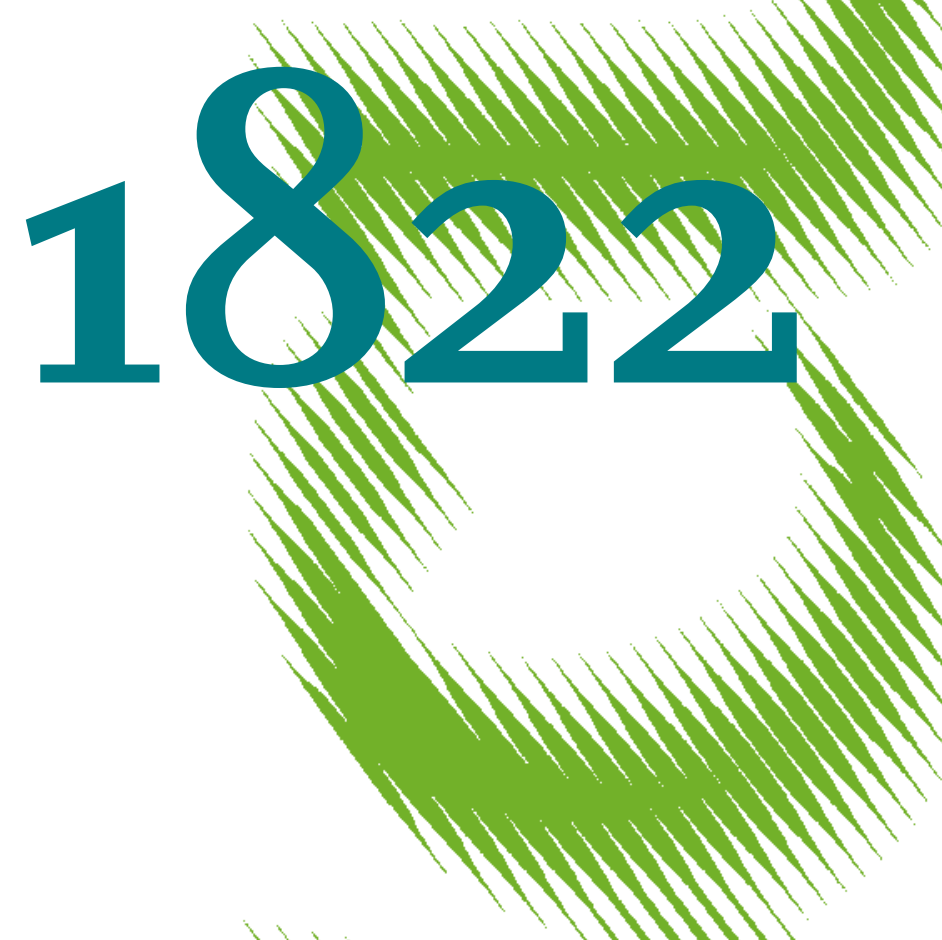

The Nexus between Loan Portfolio Size and Volatility: Does Banking Regulation Matter? 
Opinions expressed in this paper are those of the author(s) and do not necessarily reflect views of the institute.

IMPRESSUM

(C) DIW Berlin, 2019

DIW Berlin

German Institute for Economic Research

Mohrenstr. 58

10117 Berlin

Tel. +49 (30) $89789-0$

Fax +49 (30) $89789-200$

http://www.diw.de

ISSN electronic edition 1619-4535

Papers can be downloaded free of charge from the DIW Berlin website:

http://www.diw.de/discussionpapers

Discussion Papers of DIW Berlin are indexed in RePEc and SSRN:

http://ideas.repec.org/s/diw/diwwpp.html

http://www.ssrn.com/link/DIW-Berlin-German-Inst-Econ-Res.html 


\title{
The Nexus between Loan Portfolio Size and Volatility: Does Banking Regulation Matter?*
}

\author{
Franziska Bremus \\ German Institute for Economic Research (DIW Berlin)** \\ Melina Ludolph \\ Humboldt University of Berlin $(\mathrm{HU})^{\S}$
}

September 4, 2019

\begin{abstract}
Since the global financial crisis and the related restructuring of banking systems, bank concentration is on the rise in many countries. Consequently, bank size and its role for macroeconomic volatility (or: stability) is the subject of intense debate. This paper analyzes the effects of financial regulations on the link between bank size, as measured by the volume of the loan portfolio, and volatility. Using bank-level data for 1999 to 2014, we estimate a power law that relates bank size to the volatility of loan growth. The effect of regulation on the power law coefficient indicates whether regulation weakens or strengthens the size-volatility nexus. Our analysis reveals that more stringent capital regulation and the introduction of bank levies weaken the size-volatility nexus; in countries with more stringent capital regulation or levies in place, large banks show, ceteris paribus, lower loan portfolio volatility. Moreover, we find weak evidence that diversification guidelines weaken the link between size and volatility.
\end{abstract}

JEL-Classifications: G21, G28, E32.

Keywords: Bank size, regulation, volatility, diversification, moral hazard, power law

${ }^{*}$ This paper was written in the context of the SPP1578 "Financial market imperfections and macroeconomic outcomes", funded by the German National Science Foundation (DFG). We thank Bernd Fitzenberger, Marcel Fratzscher, Felix Noth, Lena Tonzer, as well as seminar participants at DIW Berlin and conference participants at the 16th Infiniti Conference on International Finance, the MBF International Rome Conference on Money, Banking and Finance (XXVVII Edition), and the 23rd Annual International Conference on Macroeconomic Analysis and International Finance for most helpful comments.

**German Institute for Economic Research (DIW Berlin), Mohrenstr. 58, 10117 Berlin, Germany. Email: fbremus@diw.de. Phone: +49 (0)30 89789590.

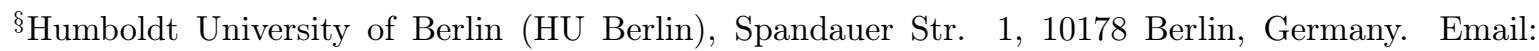
ludolphm@hu-berlin.de. 


\section{Motivation}

Since the global financial crisis, consolidation in the banking sector has led to increasing concentration (BIS, 2018; ECB, 2017). Apart from some exceptions, the share of total assets held by the five largest banks grew in several advanced economies. The recent rise of big banks fostered a renewed interest in bank size distributions and in the implications of bank-specific shocks for macroeconomic volatility (Fernholz and Koch, 2017). As demonstrated by Gabaix (2011), macroeconomic fluctuations can be explained to a significant degree by firm-level volatility, if market concentration is high; that is, if a few large players dominate the market - as is the case in manufacturing and, especially, in banking.

Different studies investigate how bank-specific shocks are related to macroeconomic fluctuations. Amiti and Weinstein (2018) as well as Buch and Neugebauer (2011) show that bank-specific credit shocks can indeed translate into aggregate movements of investment and output. The key mechanism is that bank-level volatility of loan growth translates into aggregate fluctuations in credit and output if bank concentration is very high (Bremus et al., 2018a). Yet, granular effects do not have to be strongest for the most concentrated markets, but are also fostered if average volatility is high in a given market and if the largest players are relatively volatile (Di Giovanni and Levchenko, 2012). Thus, an analysis of the volatility of loans across banks of different size is important for better understanding the linkages between fluctuations at the bank level and macroeconomic volatility.

Given the importance of bank size and volatility for macroeconomic outcomes, as well as recent regulatory reforms, this paper contributes to the literature by analyzing how financial regulation impacts the distribution of loan growth volatility at the bank level. More precisely, we addresses the question of how regulatory differences between countries affect the relation between bank size, as measured by total net loans, and the volatility 
of loan growth. If banking regulation results in large banks becoming more stable due to better diversification and if regulations ensure that banks are not becoming more volatile because of moral hazards resulting in excessive risk taking with increasing size, then not only may bank-level fluctuations be reduced, but also macroeconomic volatility.

The literature offers contrasting views on the effects that the size of a bank has on its volatility or risk profile. Some studies provide evidence that banks that are "too big to fail" take on excessive risks due to the moral hazards they face (Laeven et al., 2016; Bhagat et al., 2015; Gropp et al., 2014; Bostandzic and Weiß, 2018), thereby hinting at a positive link between bank size and risk. In addition to the z-score as a common risk measure, the literature also assesses effects of moral hazard and bank size on the volatility of earnings (Gropp et al., 2014; Laeven and Levine, 2009), on the volatility of equity returns or return on assets (Bhagat et al., 2015; Laeven and Levine, 2009), and on the volatility of net interest margins (Houston et al., 2010). In contrast to this evidence for a positive link between bank size and risk/volatility, other studies find that small banks are not well diversified and, thus, induce instability into the banking system (Landier et al., 2017; Poghosyan and de Haan, 2012; Stever, 2007; Tschoegl, 1983), which indicates a negative relationship between bank size and volatility. While an extensive body of research analyzes the effect of regulations on banks' risk-taking behavior (Andriosopoulos et al., 2015; Bhagat et al., 2015; Kroszner and Strahan, 2014), empirical evidence on the effect of different financial regulations on the link between the size of a bank and its volatility is, so far, lacking. Hence, the question of whether certain regulations result in banks becoming less volatile - e.g. due to better diversification or fewer moral hazards as they grow in size remains.

Following the literature on firm or country size and volatility, ${ }^{1}$ we estimate a power law that links bank size with the volatility of the bank's loan growth rates. We measure bank size and volatility as total net loans and the standard deviation of loan growth,

\footnotetext{
${ }^{1}$ For a summary, see Gabaix (2016).
} 
respectively, then also match balance sheet data for the 1999 - 2014 period to information on bank regulations obtained from the Systemic Crises Database (Laeven and Valencia, 2012), the World Bank Banking Supervision Survey (Barth et al., 2013), and the Macroprudential Policies Database (Cerutti et al., 2017). This results in a panel of 39,430 bank-year observations covering 24 advanced economies. The effect of a regulation on the power law coefficient indicates whether that regulation weakens or strengthens the link between bank size and volatility, hence indicating whether it supports diversification or enhances moral hazards as banks become larger. ${ }^{2}$ Thereby, we analyze whether certain financial regulations or government interventions are associated with large banks' loan portfolios being more or less volatile.

Our analysis yields three main results. First, controlling for the banks' overall conditions and country-time fixed effects, we find that more stringent capital regulation coincides with a weaker size-volatility nexus, possibly due to fewer moral hazards for large banks reflected in less loan portfolio volatility. By concept of granularity, this may lead to less macroeconomic fluctuations. Second, similarly to capital regulation stringency, imposing a bank levy seems to reduce moral hazards by promoting capitalization (Devereux et al., 2015; Célérier et al., 2018; Bremus et al., 2018b) and hence banks' skin in the game. Therefore, bank levies can also lower aggregate loan volatility in the economy. Third, we present weak evidence that the size-volatility nexus is mitigated in countries that issue diversification guidelines. This can be interpreted as an amplification of asset diversification, resulting in a less volatile loan portfolio, all else equal. Put differently, the link between bank size and volatility tends to be weaker in countries that issued diversification guidelines than in countries that did not, ceteris paribus.

The remainder of this paper is organized as follows. Section 2 reviews the literature related to the analysis in this paper. Next, we outline the theoretical concepts underlying

\footnotetext{
${ }^{2}$ Note that we do not focus on the direct effects regulatory measures have on all banks alike, small and large, rather we focus on the effects they have on the skewness of the volatility distribution, which is a function of size.
} 
the research question and the model specification in Section 3. Section 4 introduces the empirical model and discusses the selected regulations as well as the size and volatility measure. Section 5 presents the empirical results, before Section 6 concludes.

\section{Related literature}

Our analysis is closely related to the growing literature on large banks and their effect on the stability of the financial system as well as the real economy. There is a comprehensive body of literature on the relation between bank size and volatility or risk as well as on the effects of regulations on banks' risk-taking behavior.

\subsection{Bank size and volatility or risk}

Two opposing views regarding the relation between bank size and volatility or risk emerge from the literature. On the one hand, large banks that are "too big to fail" face moral hazards and, thusly, engage in risky behavior, knowing that governments must bail them out in case of distress to prevent an economic meltdown. On the other hand, some studies indicate that large banks are better diversified and, thus, more stable.

Stern and Feldman (2004) trace the roots of the moral hazard problem back to the expectations of large uninsured creditors of banks. If they can assume to be protected against any losses through government support, large banks will take on excessive risks due to suspended market discipline and distorted incentives. Laeven et al. (2016) find empirical evidence supporting this hypothesis by analyzing, in addition to systemic risk, the stock return performance of banks during the financial crisis. They show that banks with assets greater than 50 billion US dollars are riskier than small ones and that they tend to have a more fragile business model due to lower capitalization and less stable funding. Bhagat et al. (2015) confirm the positive correlation between bank size and risk, both using the z-score and the volatility of stock returns. In addition, Gropp et al. (2014) 
find that government guarantees promote banks' risk-taking, suggesting that implicitly insured large banks face moral hazards.

In contrast, Stever (2007) provides circumstantial evidence that small banks exhibit more risky loan portfolios as they lack the ability to properly diversify due to their smaller volume of total loans, due to less diversity with respect to the borrower type since they cannot extend credit to large borrowers, and due to geographic restrictions. ${ }^{3}$ Tschoegl (1983) considers a firm as a portfolio of projects that can be correlated implying that larger firms consist of more projects and, therefore, are better diversified. He finds that volatility of asset growth decreases with the size of a bank. While Landier et al. (2017) find larger banks to be less volatile as well, they hint at the relationship between bank size and volatility being rather weak. ${ }^{4}$ Based on US data for the 2004-2009 period, Poghosyan and de Haan (2012) find a negative correlation between bank size and earnings volatility. However, this negative correlation becomes weaker the higher banking sector concentration is.

Overall, the literature on the nexus between bank size and volatility or risk presents mixed results. While some studies find a negative relation, others show that larger banks tend to be more risky. These seemingly contradicting results partly arise due to differences in how bank risk or volatility and size are measured as well as due to non-linearities in the link between size and risk or volatility.

In contrast to previous studies, this paper does not test whether the diversification or the moral hazard hypothesis is valid. Rather, we aim at evaluating the strength of the link between bank size and volatility as a function of regulatory measures and interventions. Thus, we contribute to the literature by focusing on the implications of different regulatory interventions on the nexus between bank size and volatility.

\footnotetext{
${ }^{3}$ For the case of non-financial firms, Herskovic et al. (2017) also point to a negative correlation between firm size and volatility as large firms have a broader customer base that improves diversification.

${ }^{4}$ According to their estimation, multiplying bank size by a factor of 1,000 results in a mere reduction of loan growth volatility of about 3.8 percentage points.
} 


\section{$2.2 \quad$ Regulations and risk-taking}

In response to tightened regulation following the crisis, particularly for large banks, a growing literature deals with the impact of financial regulation on banks' risk-taking incentives. Drawing on cross-country differences in regulations, Andriosopoulos et al. (2015), for example, find a positive link between global banks' risk-taking and the existence of a deposit insurance scheme during the recent credit and sovereign debt crisis. Thus, deposit insurance seems to enhance the moral hazard banks are facing. Similarly, Dam and Koetter (2012) provide evidence that moral hazard as measured by bailout expectations, leads to additional bank risk-taking. Bhagat et al. (2015) show that financial firms engage in excessive risk-taking mainly through increased leverage. Therefore, supervision should focus on capital requirements. Looking at US data from 1976 to 1994, Kroszner and Strahan (2014) demonstrate that the elimination of geographic restrictions on bank activities that limit competition and diversification reduces the riskiness of banks.

However, a number of studies suggest that the impact of regulations on banks' risktaking behavior depends on certain characteristics of the regulated financial institution. While capital requirements might reduce risk in general, this effect seems to be considerably weaker, if not reversed, for banks with market power, demonstrating less portfolio risk and a lower probability to default (Agoraki et al., 2011). Devereux et al. (2015) provide evidence that setting incentives for banks to increase capital buffers leads to reduced funding risk but, at the same time, to higher portfolio risk. While activity restrictions, like prohibiting banks from trading securities or providing insurance, are insignificant when it comes to reducing risk for all banks, such restrictions do significantly reduce the credit and default risk of banks with market power (Agoraki et al., 2011). Such differences across banks in the effect regulations have on risk-taking can also be found when accounting for the ownership structure (Laeven and Levine, 2009; Klomp and de Haan, 2012) or risk profile (Klomp and de Haan, 2012). Hence, some studies already focus on differences in bank characteristics when estimating the effects of banking regulation on bank-level risk. 
However, empirical evidence on how different financial regulations affect the link between the size of a bank and the volatility of its loans is so far lacking.

\section{Bank size and volatility: theoretical background}

Idiosyncratic shocks to large banks can have effects beyond the micro-level, especially if concentration or volatility at the level of the largest institutions is high. Before analyzing how effective certain regulations are in reducing volatility as banks grow in size, we briefly lay out the theoretical foundations of our analysis.

\subsection{The concept of granularity}

Idiosyncratic shocks to firms can translate into macroeconomic fluctuations if market concentration is sufficiently high (Gabaix, 2011; Di Giovanni and Levchenko, 2012; Di Giovanni et al., 2014). This is referred to as the concept of granularity. Gabaix $(2011,2016)$ shows that Gibrat's law - which states that shocks to firm size are random and independent of a firm's absolute size - results in the firm size distribution following a power law. If this distribution is fat-tailed with a few large players dominating, the Central Limit Theorem ceases to hold and individual shocks to large firms do not average out in the aggregate but can have macroeconomic effects.

Amiti and Weinstein (2018) provide empirical evidence that the concept of granularity also applies to the banking sector. Analyzing linked bank-firm data over the 1990 - 2010 period, they show that bank-specific credit-supply shocks account for 30 to 40 percent of aggregate loan and investment fluctuations in Japan. Based on a discrete choice model with heterogeneous banks, Bremus et al. (2018a) demonstrate that idiosyncratic shocks to bank lending can generate aggregate fluctuations in credit supply if the distribution of bank sizes measured by bank loans follows a fat-tailed power law and if bank-specific shocks are passed through to firms via changes in lending rates. The empirical analysis 
confirms that the right tail of the bank size distribution in many countries indeed follows a fat-tailed power law, i.e., large banks dominate the credit market.

The concept of granularity implies that macroeconomic volatility can be reduced through two channels. On the one hand, policies that mitigate bank concentration dampen the transmission of bank-level volatility to the macroeconomy. On the other hand, microprudential regulation might induce less excessive risk-taking and better diversification at the level of (large) banks and, thereby, also mitigate volatility at an aggregate level. Hence, it is crucial to understand which regulatory measures are effective in reducing volatility, especially at the level of large banks that dominate the credit market.

\subsection{A power law linking bank size and volatility}

Gabaix (2016) argues that the volatility of firm growth - in our case banks - varies with size. He suggests that not only does the distribution of sizes follow a power law, but also the volatility of growth rates as a function of the size: $s d($ growth $)=k(\text { size })^{\alpha}$. Log linearizing yields

$$
\ln (\operatorname{sd}(\operatorname{growth}))=\ln (k)+\alpha \ln (\text { size })
$$

where $s d($ growth $)$ is the standard deviation of banks' growth rates, size is bank size measured, e.g., by total assets or loans, $k$ is a constant, and $\alpha$ is a parameter governing the relation between bank size and volatility.

If the volatility of the growth rate is independent of the bank size, the observed power law coefficient will be $\alpha=0$. If volatility increases (decreases) in bank size, $\alpha$ will be positive (negative). According to the moral hazard hypothesis, the power law coefficient should be positive $(\alpha>0)$, implying that larger banks take on higher risks, which results in a higher volatility of their growth rates compared to those of smaller banks. In contrast, the diversification hypothesis would imply a power law coefficient of $\alpha \in[-0.5,0)$ suggesting that larger banks are better diversified and, hence, have more 
stable growth rates. ${ }^{5}$

Thus, regulations that increase moral hazards or reduce diversification of large banks in particular should increase the parameter $\alpha$. In turn, regulatory measures that promote diversification or mitigate moral hazards for large banks will reduce the parameter $\alpha$. Note that regulatory measures that affect all banks alike, small and large ones, will have no effect on the nexus between bank size and volatility, i.e., the parameter $\alpha{ }^{6}$

\section{Empirical methodology and data}

Bank-specific volatility does not just depend on a bank's size but also on a number of other variables. Those covariates can either be bank-specific, country-specific or capture the global economic development. We exploit differences in regulatory measures across countries and time to identify the effect of different regulations on the size-volatility nexus in banking.

\subsection{Model specification}

For our model specification, we follow Beck et al. (2013), who use a similar approach to estimate the impact of cross-country differences in market and institutional features on the link between bank competition and stability. Building on the power law linking bank size and volatility described in equation (1), we specify our model as follows:

$$
\ln \left(\operatorname{sd}\left(\operatorname{growth}_{i, j, t}\right)\right)=\ln (k)+\alpha \ln \left(\operatorname{size}_{i, j, t}\right)+\gamma X_{i, j, t-1}+\eta_{j, t}+\epsilon_{i, j, t}
$$

\footnotetext{
${ }^{5}$ Note that the power law coefficient has a lower bound since the Central Limit Theorem holds for $\alpha=-0.5$. Then, volatility converges toward zero as size goes to infinity given the sample of bank sizes is a sequence of independent and identically distributed random variables drawn from a distribution with $E\left[\right.$ size $\left._{i}\right]=\mu$ and finite variance. Hence, full diversification could be achieved.

${ }^{6}$ Instead of affecting the skewness of the volatility distribution depending on size, these measures would shift the entire distribution.
} 
with $i$ being the index for banks, $j$ indicating the country and $t$ the year. In order to analyze how regulatory measures affect the link between bank size and volatility, we assume that time-varying and county-specific regulations explain part of the heterogeneity in the conditional correlations between bank size and volatility, then we impose the following structure on the power law parameter: $\alpha\left(Z_{j, t}\right)=\theta_{0}+\theta_{1} Z_{j, t}$, with $Z_{j, t}$ being the time-varying, country-specific regulations. Then, equation (2) becomes

$$
\ln \left(\operatorname{sd}\left(\operatorname{growth}_{i, j, t}\right)\right)=\ln (k)+\left(\theta_{0}+\theta_{1} Z_{j, t}\right) \ln \left(\operatorname{size}_{i, j, t}\right)+\gamma X_{i, j, t-1}+\eta_{j, t}+\epsilon_{i, j, t} .
$$

The parameter $\theta_{0}$ reflects the direct link between bank size and the volatility of its loan growth. Our parameter of interest - $\theta_{1}$ - indicates how different regulatory measures across countries $Z_{j, t}$ affect the size-volatility nexus. Positive (negative) values of $\theta_{1}$ imply that a regulatory measure tends to have an increasing (decreasing) effect on the power law coefficient $\alpha$ and, hence, results in large banks being, ceteris paribus, more (less) volatile.

Given that we aim at investigating the role of cross-country differences in regulations on the size-volatility nexus, we include country-and-time fixed effects $\eta_{j, t}$ in all regressions to capture any direct effects of time-varying, country-specific regulations or other potential confounding factors on bank-level volatility. By including country-and-time fixed effects, we only examine the link between the deviations of bank size from the annual countrymean $\left(S i z e_{i, j, t}-\overline{S i z e}_{j, t}\right)$ and the corresponding deviation of bank-level volatility $\left(S D_{i, j, t}-\right.$ $\left.\overline{S D}_{j, t}\right)$, as well as how this link is influenced by regulations $Z_{j, t}$ that differ across countries and over time. Hence, only the within country-year variation is considered. We do not estimate the effects of regulations on the loan portfolio volatility of banks explicitly because we are only interested in the impact of differences in banking regulations on the nexus between volatility and size - as measured by $\theta_{1}$.

To control for confounding factors that may affect volatility at the bank level, we include a set of standard variables that reflect bank performance $X_{i, j, t-1}$, all lagged by 
one year.

Standard errors are clustered at the bank level to account for potential remaining correlation of the residuals across time. Given that we only have 24 countries in our sample, clustering at the country-level entails the problem that the standard errors are biased due to the limited number of clusters (Petersen, 2009). Thus, we opt for clustering standard errors at the bank level, but also test the robustness of our results when clustering at the country level.

\subsection{Hypotheses about the effects of regulations on the size-volatility nexus}

We examine regulations from which the expected effect on the nexus between bank size and volatility can be directly derived from the theoretic arguments made by proponents of the diversification or moral hazard hypothesis. Moreover, we include regulations that have been at the focus of regulators since the financial crisis of 2007/08 (Laeven and Levine, 2009). Table 1 summarizes the sign of the expected effects and the channel through which the size-volatility nexus can be affected.

Having more stringent capital regulations or imposing a bank levy - the former being often examined in studies analyzing risk-taking behavior by banks (Andriosopoulos et al., 2015; Agoraki et al., 2011; Houston et al., 2010; Laeven and Levine, 2009) - could either prevent banks from better diversifying or mitigate the moral hazards they are facing. Regarding diversification, tighter capital requirements or a levy on liabilities imposes restrictions on the use of the financial means that prevent banks from better diversifying their asset portfolio. Devereux et al. (2015) find empirical evidence that banks exposed to levies increase their capitalization. As levies are typically imposed on the liabilities net of equity and deposits, banks tend to shift risks from the liability to the asset side resulting in higher portfolio risk manifested in a higher level of loan charge-offs. According to 
the moral hazard hypothesis, however, higher capitalization can help prevent banks from taking on excessive risks. Hence, the ultimate effect on the nexus between bank size and volatility remains ambiguous $\left(\theta_{1}>0\right.$ or $\left.\theta_{1}<0\right)$.

Following the diversification hypothesis, issuing explicit and quantifiable guidelines for asset diversification, which includes prescribing limits on loans to individual borrowers as well as on geographical and sectoral exposures, is supposed to result in more stable (large) banks (Houston et al., 2010; Doerr and Schaz, 2019). Consequently, this regulatory measure should weaken the link between bank size and volatility $\left(\theta_{1}<0\right)$.

In contrast, restrictions on bank activities like prohibiting banks from engaging in real estate activities should have a positive effect on the nexus between bank-level volatility and size $\left(\theta_{1}>0\right)$ as they prevent banks from diversifying. This argument is brought forward in the literature on bank risk-taking behavior repeatedly (Andriosopoulos et al., 2015; Agoraki et al., 2011; Houston et al., 2010; Laeven and Levine, 2009).

According to the moral hazard hypothesis, bank guarantees amplify excessive risktaking (Gropp et al., 2014), especially of large banks. Hence, bank guarantees can be expected to increase the power law coefficient $\alpha\left(\theta_{1}>0\right)$, thereby leading to smaller reductions (or: higher increases) in loan growth volatility as bank size increases.

A high degree of independence of the supervisory authority implies that regulators are less prone toward any influences of politics or banks. Therefore, moral hazards should be attenuated. As large banks typically have greater lobbying power and political significance than small banks, a higher degree of the supervisory authority's independence can be expected to have a negative impact on the size-volatility link $\left(\theta_{1}<0\right)$, thus leading to a more pronounced reduction in bank-level volatility for larger banks.

Strengthening private monitoring might alleviate excessive risk-taking (Andriosopoulos et al., 2015; Klomp and de Haan, 2012; Houston et al., 2012). Again, this argument seems to apply to large banks in particular: They are likely to meet a greater proportion 
of their funding needs by accessing the capital markets. Therefore, they may be subjected to private monitoring more effectively. Hence, stronger private monitoring could result in a weaker nexus between bank size and volatility $\left(\theta_{1}<0\right)$.

Another regulation at the focus of the ongoing policy debate are capital surcharges for systemically important financial institutions (SIFIs). The goal is to reduce moral hazard and, hence, excessive risk-taking by large banks. Information on whether a country imposes capital surcharges on large banks is found in the Macroprudential Policies Database (Cerutti et al., 2017). However, there is almost no variation in the data for our sample as capital surcharges on SIFIs were rarely imposed in advanced economies prior to 2012 . Therefore, we disregard this regulation in our analysis. A similar argument applies to geographic lending restrictions, which might prevent banks from better diversifying as they grow in size. However, banks were permitted to extend credit to foreign entities in almost all advanced economies during the sample period.

\subsection{Measuring bank-level volatility, size and overall conditions}

\subsubsection{Bank-level volatility}

Amiti and Weinstein (2018) as well as Bremus et al. (2018a) show that the concept of granularity applies to the banking sector if idiosyncratic shocks are passed through to firms via changes in lending. Since we are interested in bank-level volatility that might cause macroeconomic fluctuations through the mechanism of granularity, we need a measure of the volatility of loans at the bank level, namely the standard deviation of a bank's growth in net loans. Thereby, our results might give some indications regarding the impact of financial regulations on macroeconomic volatility.

Directly calculating the annual standard deviation of the growth in net loans would require intra-year data on lending of banks, which is not available for large cross-country datasets. Due to the unbalanced nature of our panel, calculating annual standard deviati- 
ons based on rolling windows over several consecutive years is likely to produce inaccurate estimates. Instead, we follow Loutskina and Strahan (2015) and Kalemli-Ozcan et al. (2014), regressing bank-level loan growth on a set of time and bank fixed effects,

$$
\frac{\text { loans }_{i, t}-\text { loans }_{i, t-1}}{\text { loans }_{i, t-1}}=\beta_{t}+\delta_{i}+\text { shock }_{i, t},
$$

where $\beta_{t}$ is the time fixed effect capturing the average growth of all banks, i.e., the effect of common macroeconomic factors in year $t$, and $\delta_{i}$ is the bank fixed effect capturing the average growth over time of bank $i$, i.e., the effect of time-invariant, bank-specific

factors like the bank type or its business model. Consequently, the $s_{h o c k}$ reflects how much loan growth of bank $i$ differs from the average loan growth across all banks in year $t$ and from the average loan growth of bank $i$ over time. As equation (4) is estimated country-by-country, the shock captures deviations of bank-level loan growth from the annual country-mean. We then use the absolute value of the estimated residuals as our time-varying annual volatility measure:

$$
\operatorname{sd}\left(\operatorname{growth}_{i, t}\right):=\left|\widehat{\operatorname{shock}}_{i, t}\right|
$$

\subsubsection{Bank size}

Although bank size is often measured by total assets (Laeven et al., 2016; Bhagat et al., 2015; Houston et al., 2010), in our context, total net loans are a more appropriate measure of bank size as we are ultimately interested in the real macroeconomic effects of bank-level volatility, which are more closely related to credit supply rather than to total bank assets (Bremus and Buch, 2017). Moreover, granular effects from the banking sector are shown to transmit to the macroeconomy through loans (Amiti and Weinstein, 2018).

Figure 1 shows that the average bank loan portfolio size increases over the sample period, while the median remains fairly constant. This indicates that large banks dispro- 
portionately expanded their loan portfolios, hinting toward an increase in market concentration in the credit market - a topic of increasing debate since the global financial crisis. $^{7}$

To visualize the variation in the power law coefficient $\alpha$ that links size with volatility of a bank's loan portfolio over time and across countries, Figure 2 shows the linear fit of the power law introduced in equation (1) for four sub-periods in each country. Overall, the nexus seems to be negative in the majority of the cases, indicating that volatility increases with bank size, which is in line with the existing findings of Landier et al. (2017). However, while the size-volatility nexus remained fairly stable over time in some countries (e.g., France, Japan, Netherlands), we can observe variation in the power law coefficient over time in others (e.g., Belgium, Germany, Portugal). In certain countries, the nexus even changed from positive to negative or vice versa (e.g., Austria, Italy, Slovenia).

In summary, the power law coefficient $\alpha$ varies substantially between countries and across time periods. The extent to which this variation across countries and over time in the power law coefficient $\alpha$ can be explained by differences and changes in regulatory frameworks is the question at hand.

\subsubsection{Bank-level controls}

We are interested in the effect of different regulations on the link between size and volatility. Thus, we control for confounding factors that drive volatility at the bank level. To account for the bank's overall condition, we follow the literature (e.g. Lambert et al. (2017)) and include a set of standard bank-level characteristics that relate to banks' capital adequacy, asset quality, management capability, earning, and liquidity (CAMEL).

\footnotetext{
${ }^{7}$ In the aftermath of the financial crisis, bank concentration significantly increased in several countries, e.g., due to mergers and takeovers of failing banks (BIS, 2018; ECB, 2017). In the United States, while the biggest five banks accounted for about ten percent of total bank assets at the beginning of the 1990s, in the mid-2010s, these banks owned nearly half of total bank assets (https://politicsofpoverty.oxfamamerica.org/2016/01/toobig-to-fail-and-only-getting-bigger/).
} 
We measure capital adequacy by the commonly used equity-to-assets ratio (Bhagat et al., 2015; Houston et al., 2010). Typically, a higher equity-to-assets ratio is associated with a higher degree of bank stability as equity serves as a cushion against asset malfunction. A rise in equity might indeed increase the bank's protection against loan losses suggesting a negative effect of the capital adequacy ratio on loan volatility. However, the effect of a higher equity-to-assets ratio on the volatility of the loan portfolio could also be positive: The ratio increases with decreasing total assets, which might arise from cutting back the loan portfolio. Since a smaller loan portfolio is likely to be less diversified, this might result in higher volatility.

Following Beck et al. (2013), we measure asset quality by loan loss provisions over net interest revenues. Ideally, this ratio is as low as possible. A high-risk lending book should be reflected in high interest margins. If asset quality deteriorates and the ratio increases, volatility of the loan portfolio is expected to rise.

Management capability is measured by non-interest expense over gross revenues (Agoraki et al., 2011). This ratio reflects the costs of running a bank as a percentage of net income before impairment charges. A lower ratio indicates a more efficiently operating bank. Therefore, there could be a positive effect on bank-level volatility. However, management capability does not necessarily affect loan portfolio volatility.

The ability of a bank to generate earnings is most commonly measured by the returns on average assets (ROAA) (Bhagat et al., 2015; Houston et al., 2010; Jiménez et al., 2013). The higher the returns generated from the assets financed by the bank, the more stable a bank is. Thus, the effect of ROAA on loan portfolio volatility can be expected to be negative.

Finally, we control for liquidity measured by net loans relative to assets (Laeven et al., 2016; Beck et al., 2013). The higher this ratio, the less liquid the bank is, as more assets are tied up in loans. The effect on loan portfolio volatility is expected to be negative: an increase in net loans over total assets indicates a more traditional and stable banking 
strategy focusing on lending business rather than investment banking activities. Moreover, a larger loan portfolio is likely to be better diversified and might, therefore, exhibit lower volatility. ${ }^{8}$

\subsection{Data sources}

\subsubsection{Bank balance sheet data}

To estimate our model, we use annual data covering the 1997 - 2014 period from the Bureau Van Dijck Bankscope database, which contains information on bank balance sheets worldwide.

We conduct several pre-processing steps to deal with issues typically arising when working with Bankscope (Duprey and Lé, 2016). First, we adjust for different accounting dates since we need consistent yearly observations to be able to match later the bank data to information on regulations. If a bank publishes its financial statements in the first half of a year, it is categorized to be referring to the previous full year. Second, to account for reporting errors, we perform some plausibility checks. We check whether reported net loans, loan loss provisions, and the measure for management capability being noninterest expense over gross revenues are larger than 0 and whether the capital adequacy ratio measured as equity over total assets as well as the liquidity control variable being net loans over total assets are $\in[0,1]$. All entries that do not fulfil these conditions - well below one percent of observations per variable - are dropped. As some banks publish consolidated as well as unconsolidated statements, the dataset might include double entries. Following previous literature, e.g. Claessens and von Horen (2015) or Buch and Neugebauer (2011), we only keep banks that have a consolidation code of C1 (i.e., published statements are consolidated and companions are not in the dataset), C2 (i.e., published statements are consolidated and companions are in the dataset), U1 (i.e.,

\footnotetext{
${ }^{8}$ For more details on how we measure the control variables, see Table 8 in the Data Appendix.
} 
published statements are unconsolidated and companions are not in the dataset or the bank does not publish consolidated accounts), or A1 (i.e., statements are aggregated with no companion). Since we are particularly interested in the effects different regulatory measures have on the link between the loan portfolio size and volatility of large banks, we disregard all banks with assets less than $0.005 \%$ of total bank assets in a given countryyear. Thereby, we loosely follow a categorization by the ECB, which defines banks to be very small if a bank's assets as a percentage of total assets of EU banks is below this threshold. This selection results in a mere reduction of $2 \%$ in the sample mean of assets.

To ensure some degree of comparability, we analyze the effect of different banking regulations on the nexus between loan portfolio size and volatility across advanced economies as defined by the International Monetary Fund (IMF, 2012). We disregard developing countries in our analysis to prevent any distorting effects arising from possible deviations between de jure and de facto banking regulations. Moreover, the financial crisis of $2007 / 08$, which triggered many of the regulatory changes in recent years had less impact on the banking sectors in developing countries compared to those in advanced economies.

We exclude all banks and country-years with fewer than five observations, as our timevarying and bank-specific volatilities are measured as the absolute value of the estimated residuals from regressing bank-level loan growth on a set of time and bank fixed effects in each country. Moreover, we only keep countries in the sample for which we have at least 50 bank-year observations. ${ }^{9}$ In terms of bank types, the dataset includes bank holding and holding companies (12\%), commercial banks (30\%), cooperative banks (32\%), and savings banks $(26 \%)$. We exclude various specialized banks to focus on the traditional credit business.

After estimating the bank-specific volatilities according to equations (4) and (5), we

\footnotetext{
${ }^{9}$ Our baseline results are not sensitive to these selection criterions. The main empirical findings do not change if the number of necessary bank-year observations for a country to be included in the panel is any number between 25 and 75 . The same holds true for the number of country-year and bank observations being set as small as three and as large as seven.
} 
winsorize all bank-level variables (volatility, size, and bank-specific controls) at a one percent level from above and below to reduce distorting effects arising from outliers and potential mismeasurement (Kalemli-Ozcan et al., 2014; Beck et al., 2013). ${ }^{10}$ Our final regression sample covers the 1999 - 2014 period. $^{11}$

\subsubsection{Data on regulations and interventions}

We obtain the data for the regulatory variables from four main sources. Laeven and Valencia (2012) provide data on bank guarantees in their Systemic Crises Database. The information on whether a country imposed a levy or tax on financial institutions is obtained from the Macroprudential Policies Database compiled by Cerutti et al. (2017). These data are combined with information from Devereux et al. (2015), as laid out in more detail by Bremus et al. (2018b). All other regulatory variables are taken from the World Bank Banking Supervision Survey by Barth et al. (2013). For more details on how we measure the regulations, see Table 9 in the Data Appendix. Unfortunately, the databases do not cover the entire sample period. Therefore, we must hold some variables constant over certain sub-periods as is done in previous studies that used indices from the World Bank Banking Supervision Survey (Beck et al., 2013; Houston et al., 2012). The Systemic Crises Database ends in 2011. Thus, we hold the last observations constant for the period 2012 to 2014. The Macroprudential Policies Database starts in 2000. Hence, we assume the regulatory measure to be unchanged for the period from 1999-2000. The World Bank Banking Supervision Survey was conducted in four waves referring to the regulatory situation in a country one year prior to its publication (Barth et al., 2013). Therefore, data are available for the years 1999, 2002, 2006, and 2011. We choose to hold the variables constant for the periods from 1999-2001, 2002-2005, 2006-2009, and 2010-2014. Thereby,

\footnotetext{
${ }^{10}$ Winsorizing at any other level between 0.5 and 2.5 percent does not affect our baseline results.

${ }^{11}$ The pre-processed data covers the period from 1999 to 2014 for the size and volatility measure, whereas it covers the period from 1998 to 2013 for the variables describing the banks' overall conditions as we use lagged controls.
} 
we try to account for the changes in regulation that occurred in response to the crisis but were introduced only after several years (e.g. Dodd-Frank Act in 2010, Basel 2.5 in 2011). ${ }^{12}$

After matching the bank data with the data on regulations, we again exclude all banks and country-years with less than five observations and all countries for which we do not have at least 50 bank-year observations. ${ }^{13}$ This yields a panel consisting of 39,430 bank-year observations covering 4,335 banks in 24 advanced economies. Note that each regulatory measure included in our regression analysis has a variance inflation factor of less than 1.5. Tables 2 and 3 present summary statistics and correlations, respectively, of the regulatory variables for our sample. For a list of the countries included in the panel, see Table 4.

\section{$5 \quad$ Estimation results}

To estimate the effect of different regulations on the nexus between bank size and volatility, we estimate the model presented in equation (3). All regressions include country-and-time fixed effects, and standard errors are clustered at the bank level.

\subsection{Regulations and the size-volatility nexus}

Table 5 presents our baseline regression results. To start with, all bank-level control variables, except for ROAA, enter the model significantly and show the expected effects. A higher capital adequacy has a positive significant effect on loan portfolio volatility,

\footnotetext{
${ }^{12}$ Our baseline results prove to be robust against changing the periods for which we hold the variables constant to 1999-2000, 2001-2005, 2006-2009, and 2010-2014 as well as to 1999-2000, 2001-2004, 20052009, and 2010-2014.

${ }^{13}$ This reduces the total observations by approximately $3.5 \%$. The average standard deviation and loan portfolio size of the sample shrinks by less than $1 \%$ and $3 \%$, respectively. The results remain unchanged when estimating our baseline model with the larger panel.
} 
suggesting that a higher equity-to-assets ratio might arise from a reduction of the loan portfolio, rendering it more volatile. A lower asset quality and management capability measured through higher loan loss provision over net interest revenues and higher noninterest expense over gross revenues, respectively, result in higher loan portfolio volatility. As expected, an increase in net loans over total assets mitigates volatility, suggesting that a larger loan portfolio is likely to be better diversified. A higher ability to generate earnings, measured by ROAA, does not significantly affect loan portfolio volatility in our sample.

Considering the variation in regulations across countries and over time, the results reveal that effects on the bank size-volatility nexus differ substantially across regulatory measures. We find a negative and highly statistically significant effect for capital regulation stringency (columns $(1)$ and $\left.(2), \theta_{1}<0\right)$. More stringent capital regulation reduces loan portfolio volatility as banks become larger. This supports the moral hazard hypothesis, suggesting that better capitalization makes loans issued by large banks less volatile.

Moreover, we find a significant and negative effect for imposing a levy or tax on bank liabilities (columns (1) and (3)). In line with the finding for capital regulatory stringency, if a levy or tax is in place, particularly large banks become, ceteris paribus, more stable.

Additionally, issuing diversification guidelines has a negative and weakly significant effect on the nexus between loan portfolio size and volatility (column (1)), suggesting that such guidelines encourage banks to better diversify as they grow in size. Hence, large banks become less volatile if diversification guidelines are issued, all else being equal. By encouraging diversification, the nexus between loan portfolio size and credit growth volatility is significantly decreased. However, this effect turns insignificant when estimating the model including no regulations other than diversification guidelines (column (2)). Issuing diversification guidelines is likely to be a proxy for more explicit supervisory interventions not captured by the regulatory measures included in our model. According to Barth 
et al. (2013), guidelines may prescribe, for instance, loan exposure limits to individual borrowers as well as to regional, geographical and sectoral exposures.

Regarding economic significance, the estimation results reveal that as bank size increases by one standard deviation from the sample mean, loan portfolio volatility rises by approximately $11 \%$ in countries with the most lenient capital regulations. In contrast, in countries with the most stringent capital regulations, volatility declines by $20 \%$ with a one standard deviation increase in bank size. ${ }^{14}$ In countries where a levy or tax is imposed on banks, loan portfolio volatility falls by about $21 \%$, compared to a decline in volatility by a mere $7 \%$ in countries without a tax or levy (column (7) in Table 5).

Activities restrictions, bank guarantees, private monitoring, and supervisory independence do not show significant effects on the size-volatility nexus in our baseline sample.

Regarding the overall link between loan portfolio size and volatility, the power law coefficient $\alpha$ - computed from the estimated coefficients on $\ln ($ size $)$ and the effects of a certain regulatory measures times the sample mean of this regulation $\left(\theta_{0}+\theta_{1} \bar{Z}_{j, t}\right)-$ is negative in all regression models, thus indicating that volatility generally decreases in loan portfolio size. This is in line with related studies, e.g. Landier et al. (2017).

The estimation results for our sample disregarding banks with loan portfolio sizes below certain thresholds are presented in Table 6. Interestingly, issuing diversification guidelines becomes statistically more significant when excluding very small banks, i.e., banks with a loan portfolio size of less than 250 and 500 million US dollars, respectively. This is plausible given that small banks might be unaffected by such guidelines as they lack access to different regions, sectors or a large variety of borrowers. However, we find that the effect disappears when only banks with a loan portfolio larger than 1 billion US dollar

\footnotetext{
${ }^{14}$ At the sample mean of bank size (8.55), an increase in size by one standard deviation (33.75) corresponds to a $394.7 \%$ increase in size. Capital regulatory stringency is measured by an indicator that varies between 2 and 9 for our sample (see Table 2). Hence, based on column (6) in Table 5, the marginal effect of bank size on volatility amounts to $394.7 *(0.0504-0.0112 * 2)$ if the most lenient capital regulations are in place and to $394.7^{*}\left(0.0504-0.0112^{*} 9\right)$ in case of the most stringent capital regulations.
} 
are included in the sample (column (4)). Hence, the link between loan portfolio volatility and size is not weakened by diversification guidelines if the nexus is only considered for very large banks. Any guidelines or loan exposure limits seem to become irrelevant, suggesting that they are likely to be satisfied anyway.

The level of statistical significance of capital regulation stringency is fairly stable with respect to the minimal size of the banks included in the sample. Yet, the absolute value of the negative coefficient more than doubles if only banks with a loan portfolio of at least 2 billion US dollar are included in the sample (column (5)) compared to the result for the sample including all banks with loan portfolios larger than 100 million US dollar (column (1)). Hence, imposing more stringent capital regulation on banks reduces the link between loan portfolio volatility and size for medium-sized and large banks, that is, for those banks more affected by the regulation. Imposing a levy or tax no longer reduces the size-volatility nexus at a statistically significant level if the sample includes only banks with loan portfolios of at least 500 million US dollar (column (3)).

We find some counter-intuitive outcomes for supervisory independence, activities restrictions and bank guarantees. However, they are only weakly statistically significant and not robust against changes in the sample. Moreover, they turn statistically insignificant when clustering standard errors at the country level.

Unsurprisingly, the significantly positive effect of our capital adequacy control variable ceases with increasing thresholds for the minimum loan portfolio size. The larger the banks are, the less pronounced the effect of cutting back the loan portfolio on their stability will be. Management capability also loses significance if the sample consists of banks with loan portfolios of at least 500 million US dollar. It seems reasonable that non-interest expense over gross revenues do not strongly affect loan portfolio volatility of large banks. The significant effects of the control variables for asset quality and liquidity are stable across the different thresholds.

In summary, our analysis shows that imposing capital regulation stringency affects 
the nexus between size measured in terms of total net loans and volatility measured as standard deviation of net loan growth. The underlying mechanism appears to be along the lines of the moral hazard hypothesis. Imposing a levy or tax on banks and issuing diversification guidelines can also result in larger reductions in volatility as banks size increases, all else being equal, if not only very large banks are considered.

\subsection{Robustness tests}

We run several alternative regressions in order to test the robustness of the results discussed above. Table 7 presents the results. The estimations are based on our model specified in equation (3). All regressions include country-and-time fixed effects and the above discussed lagged bank-specific controls.

Column (1) displays the results for estimating our model for only 21 advanced economies. Cyprus, Luxembourg, and Switzerland are excluded from the sample to ensure that the results are not driven by countries with a very dominant banking sector. We find that our previous results for capital regulation stringency is robust in both the level of significance as well as size and direction of the effect. The effect resulting from imposing a levy or tax are becomes even more pronounced in size and significance, whereas issuing diversification guidelines no longer has a significant effect.

As our sample consists of different numbers of bank-year observations for each country in the panel (Table 4), the results could be driven by the countries that constitute large shares of total observations. Therefore, we exclude Germany and the United States from the sample, the two constituting approximately $29 \%$ of our panel. Column (2) highlights that our baseline results for imposing capital regulation stringency prove to be robust. However, issuing diversification guidelines and imposing a levy or tax becomes insignificant. In contrast, we find a negative, statistically significant, effect for stronger private monitoring power. 
In column (3), the 2007 and 2008 crisis years are excluded from the sample. This change in the sample leaves our baseline results for capital regulation stringency unaffected. However, the other regulations no longer appear to have a statistically significant effect.

In column (4), size is measured by net loans over the country's GDP. ${ }^{15}$ Thereby, we analyze the link between loan portfolio volatility and size relative to the countries' GDP, i.e. the bank's systemic size (Bertay et al., 2013). Our baseline results for capital regulation stringency and imposing a tax or levy prove to be robust. This further substantiates our line of reasoning, based on the granularity hypothesis, that issuing diversification guidelines and imposing capital regulation stringency reduces the volatility of banks that are large with respect to the country's economy, all else being equal, and, thus, might reduce macroeconomic fluctuations.

In column (5), we add a quadratic term of the natural logarithm of size to the model in order to control for any non-linear effects in the log linearized size-volatility nexus. We find a positive effect of the quadratic term, whereas the direct effect of bank size measured by $\theta_{0}$ is negative. Hence, our estimation results point to a U-shaped relationship between bank size and volatility. It suggests that, for small banks, increasing the loan portfolio size is associated with a reduction in volatility (diversification hypothesis). However, once a certain threshold of loan portfolio size is reached, further extending the loan portfolio results in higher levels of volatility (moral hazard hypothesis). Our baseline findings in the linear model remain unchanged in the non-linear model.

In column (6), we add an interaction-term of our size measure with a dummy variable indicating if a bank's assets are larger than $10 \%$ of the country's GDP. The results show that our findings are robust even when controlling for the impact of too-big-to-fail banks.

In order to alleviate concerns about endogeneity regarding the relationship between

\footnotetext{
${ }^{15}$ Data on annual GDP for the countries included in the panel over the sample period is obtained from the World Bank.
} 
bank size and volatility, we perform an instrumental variable estimation (column (7)). We use bank specialization and lagged loan portfolio size as instruments for loan portfolio size. For the interactions between loan portfolio size and the different regulations, we proceed as follows (Wooldridge, 2010). In a first step, we predict loan portfolio size from a first stage regression where total net loans are regressed on the two instruments and the control variables from the baseline model. Second, we interact the prediction with the respective regulation and use the resulting variable as an instrument for the interaction term. Testing for weak instruments, the F-Statistic supports the adequacy of the instruments. The IV-results reveal that our baseline result for capital regulation stringency is robust.

Moreover, in unreported regressions, we cluster standard errors at the country level. Generally, the estimated coefficients on capital stringency remain statistically significant, even though standard errors increase. In the baseline model including all regulations together, the interaction effect between bank levies and size remains statistically significant. However, the coefficient on the interaction between diversification guidelines and loan portfolio size turns insignificant when clustering standard errors at the country level.

\section{Conclusions}

Building on the concept of granularity and motivating our model specification by the theory on power laws, our analysis provides empirical evidence that certain regulations result in banks being better diversified or facing fewer moral hazards when moving up the bank size distribution. Thereby, we close a gap in the literature, which so far focuses almost exclusively on the direct effects regulations have on the risk-taking behavior of banks.

Our analysis provides three main insights. First, imposing more stringent capital regulation has a significantly negative effect on the link between size and volatility; in 
countries with stricter capital regulation, volatility declines more with bank size than in countries with more lenient capital regulation, on average. Second, imposing a levy on bank liabilities also reduces the size-volatility nexus, suggesting that it mitigates the moral hazards large banks face. Finally, issuing diversification guidelines can result in large banks having less volatile loan portfolios, all else being equal.

One limitation of our approach concerns the origins of loan portfolio volatility. Even if we control for bank characteristics and credit demand factors at the country level through bank-level controls and country-and-time fixed effects, respectively, we cannot fully account for the fact that changes in loan volatility result from credit demand at the firm level, and thus cannot be affected by financial regulations.

Overall, the estimation results reveal that the large heterogeneity in the link between bank size and volatility across countries and time is related to differences in the regulatory framework across countries. Interventions that increase bank capitalization, like stringent capital regulation or taxes on liabilities (bank levies) appear to be effective at promoting lower loan portfolio volatility at the level of large banks, ceteris paribus, and, in turn, more stable credit extension. Thereby, the transmission of micro-level credit shocks to the macroeconomy can be mitigated through the channel of granularity. 


\section{References}

Agoraki, M.-E. K., M. D. Delis, and F. Pasiouras, "Regulations, competition and bank risk-taking in transition countries," Journal of Financial Stability, 2011, 7, 38-48.

Amiti, M. and D. E. Weinstein, "How Much do Idiosyncratic Bank Shocks Affect Investment? Evidence from Matched Bank-Firm Loan Data," Journal of Political Economy, 2018, $126(2), 525-587$.

Andriosopoulos, M.-E. K., K. Andriosopoulos, and R. Douady, "Bank regulation, risk and return: Evidence from the credit and sovereign debt crises," Journal of Banking Ef Finance, 2015, 50, 455-474.

Barth, J. R., G. Caprio, and R. Levine, "Bank regulation and supervision in 180 countries from 1999 to 2011," Journal of Financial Economic Policy, 2013, 5 (2), 111219.

Beck, T., O. De Jonghe, and G. Schepens, "Bank competition and stability: Crosscountry heterogeneity," Journal of Financial Intermediation, 2013, 22 (2), 218-244.

Bertay, A. C., A. Demirguc-Kunt, and H. Huizinga, "Do we need big banks? Evidence on performance, strategy and market discipline," Journal of Financial Intermediation, 2013, 22 (4), 532-558.

Bhagat, S., B. Bolton, and J. Lu, "Size, leverage, and risk-taking of financial institutions," Journal of Banking \& Finance, 2015, 59, 520-537.

BIS, "Structural changes in banking after the crisis," Committee on the Global Financial System, CGFS Papers No 60, January 2018.

Bostandzic, D. and G. N.F. Weiß, "Why do some banks contribute more to global systemic risk?," Journal of Financial Intermediation, 2018, 35, 17-40. 
Bremus, F. and C. M. Buch, "Granularity in banking and growth: Does financial openness matter?," Journal of Banking \& Finance, 2017, 7r, 300-316.

-, - , K. N. Russ, and M. Schnitzer, "Big Banks and Macroeconomic Outcomes: Theroy and Cross-Country Evidence of Granularity," Journal of Money, Credit and Banking, 2018.

_ , K. Schmidt, and L. Tonzer, "Interactions between regulatory and corporate taxes: How is bank leverage affected?," DIW Discussion Paper No. 175\%, September 2018.

Buch, C. M. and K. Neugebauer, "Bank-specific shocks and the real economy," Journal of Banking $\&$ Finance, 2011, 35 (8), 2179-2187.

Cerutti, E., S. Claessens, and L. Laeven, "The Use and Effectiveness of Macroprudential Policies: New Evidence," Journal of Financial Stability, 2017, 28, 203-224.

Claessens, S. and N. von Horen, "The impact of the global financial crisis on banking globalization," IMF Economic Review, 2015, 63 (4), 868-918.

Célérier, C., T. Kick, and S. Ongena, "Taxing Bank Leverage: The Effects on Bank Capital Structure, Credit Supply and Risk-Taking," Available at SSRN: https://ssrn.com/abstract=2829326 or http://dx.doi.org/10.2139/ssrn.2829326, 2018.

Dam, L. and M. Koetter, "Bank bailouts and moral hazard: Evidence from Germany," Review of Financial Studies, 2012, 25 (8), 2343-2380.

Devereux, M., N. Johannesen, and J. Vella, "Can taxes tame the banks? Evidence from European bank levies," Said Business School Working Paper, 2015, 5, 520-537.

Doerr, S. and P. Schaz, "Bank Loan Supply During Crises: The Importance of Geographic Diversification," Working Paper, University of Zurich, March 2019.

Duprey, T. and M. Lé, "Bankscope Dataset: Getting Started," Online Publication 2016. 
ECB, "Report on Financial Structures," European Central Bank, October 2017.

Fernholz, R. T and C. Koch, "Big Banks, Idiosyncratic Volatility, and Systemic Risk," American Economic Review: Papers \& Proceedings, 2017, 107 (5), 603-07.

Gabaix, X., "The granular origins of aggregate fluctuations," Econometrica, 2011, 79 (3), 733-772.

_, "Power Laws in Economics: An Introduction," Journal of Economic Perspectives, 2016, 30 (1), 185-206.

Giovanni, J. Di, A.A. Levchenko, and I. Mejean, "Firms, Destinations, and Aggregate Fluctuations," Econometrica, 2014, 82 (4), 1303-40.

_ and A. A. Levchenko, "Country Size, International Trade, and Aggregate Fluctuations in Granular Economies," Journal of Political Economy, 2012, 120 (6), 1083-1132.

Gropp, R., C. Gruendl, and A. Guettler, "The Impact of Public Guarantees on Bank Risk-Taking: Evidence from a Natural Experiment," Review of Finance, 2014, $18,457-488$.

Herskovic, B., B. Kelly, H. Lustig, and S. van Nieuwerburgh, "Firm Volatility in Granual Networks," CEPR Discussion Papers No. 12284, September 2017.

Houston, Joel F., Chen Lin, and Yue Ma, "Creditor rights, information sharing, and bank risk taking," Journal of Financial Economics, 2010, 96 (3), 345 - 526.

_ , , and _ , "Regulatory Arbitrage and International Bank Flows," Journal of Finance, September 2012, 67 (5), 1845-1895.

IMF, "World Economic Outlook - October 2012," 2012.

Jiménez, G., J. A. Lopez, and J. Saurina, "How does competition affect bank risktaking?," Journal of Financial Stability, 2013, 9 (2), 185-195. 
Kalemli-Ozcan, S., B. Sorensen, and V. Volosovych, "Deep Financial Integration and Volatility," Journal of the European Economic Association, 2014, 12 (6), 1558-1585.

Klomp, J. and J. de Haan, "Banking risk and regulation: Does one size fit all?," Journal of Banking 8 Finance, 2012, 36 (12), 3197-3212.

Kroszner, R. S. and P. E. Strahan, "Regulation and Deregulation of the US Banking Industry: Causes, Consequences, and Implications for the Future," in N. L. Rose, ed., Economic Regulation and Its Reform: What Have We Learned?, University of Chicago Press, 2014, pp. 485-543.

Laeven, L. and F. Valencia, "Systemic Banking Crises Database: An Update," IMF Working Paper, 2012, 163.

- and R. Levine, "Bank governance, regulation and risk taking," Journal of Financial Economics, 2009, 93 (2), 259-275.

_, L. Ratnovski, and H. Tong, "Bank size, capital, and systemic risk: Some international evidence," Journal of Banking 86 Finance, 2016, 69 (1), 25-34.

Lambert, C., F. Noth, and U. Schüwer, "How do insured deposits affect bank risk? Evidence from the 2008 Emergency Economic Stabilization Act," Journal of Financial Intermediation, 2017, 29, 81-102.

Landier, A., D. Sraer, and D. Thesmar, "Banking integration and house price comovement," Journal of Financial Economics, 2017, 125 (1), 1-25.

Loutskina, E. and P. E. Strahan, "Financial integration, housing, and economic volatility," Journal of Financial Economics, 2015, 115 (1), 25-41.

Petersen, Mitchell A., "Estimating Standard Errors in Finance Panel Data Sets: Comparing Approaches," Review of Financial Studies, 2009, 22 (1), 435 - 480. 
Poghosyan, T. and J. de Haan, "Bank size, market concentration, and bank earnings volatility in the US," Journal of International Financial Markets, Institutions and Money, 2012, 22 (1), 35-54.

Stern, G. H. and R. J. Feldman, Too Big to Fail: The Hazards of Bank Bailouts, Washington, D.C.: Brookings Institution Press, 2004.

Stever, R., "Bank size, credit and the sources of bank market risk," BIS Working Papers, 2007, 238.

Tschoegl, A. E., "Size, Growth, and Transnationality among the World's Largest Banks," Journal of Business, 1983, 56 (2), 187-201.

Wooldridge, Jeffrey M, Econometric analysis of cross section and panel data, MIT press, 2010. 


\section{Figures}

Figure 1: Average and median loan portfolio size over time

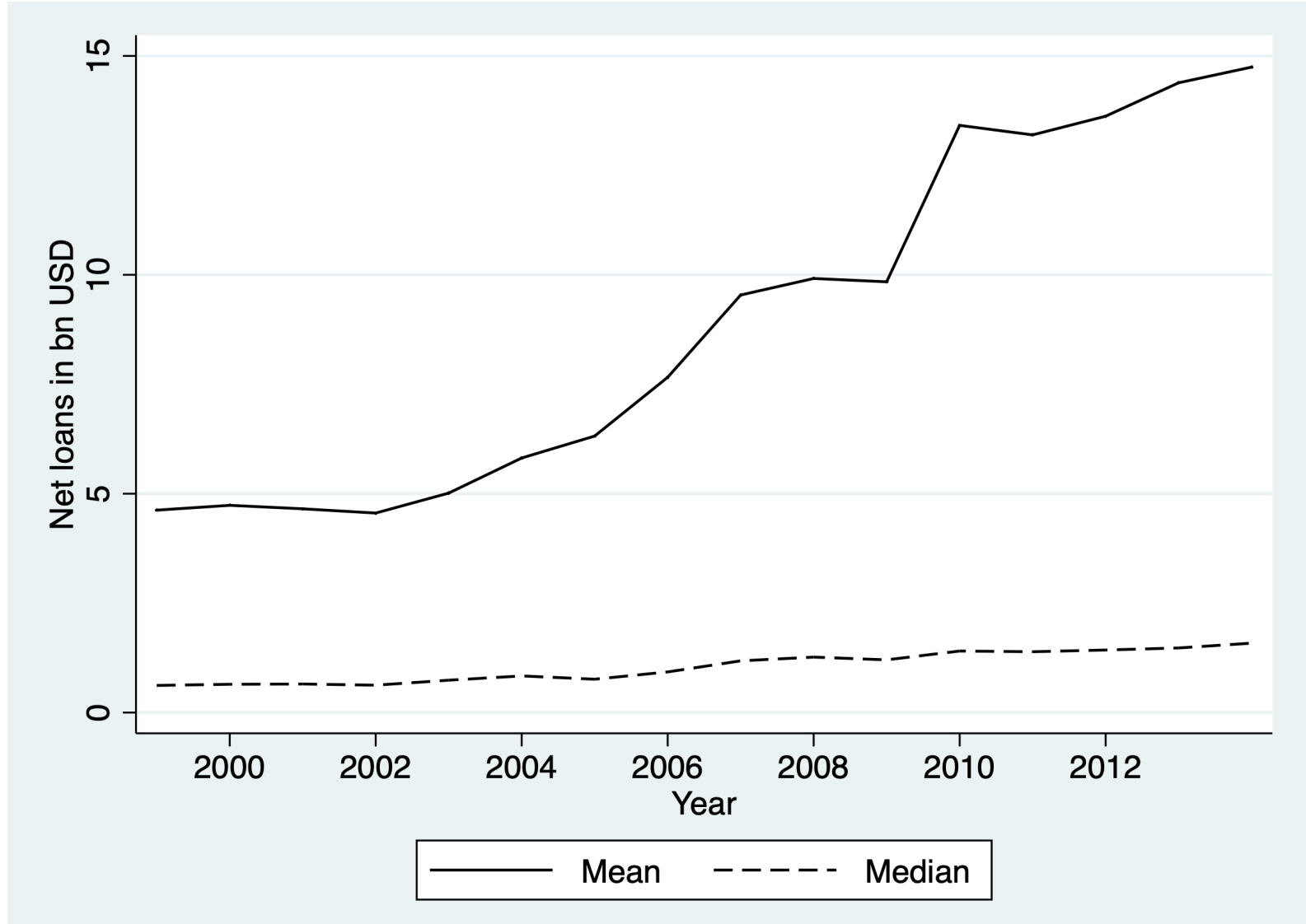

Note: This figure shows the development of the average and median size of banks' net loan portfolio in US dollar billions over the 1999 - 2014 sample period. 
Figure 2: Nexus between size and volatility of loan portfolios

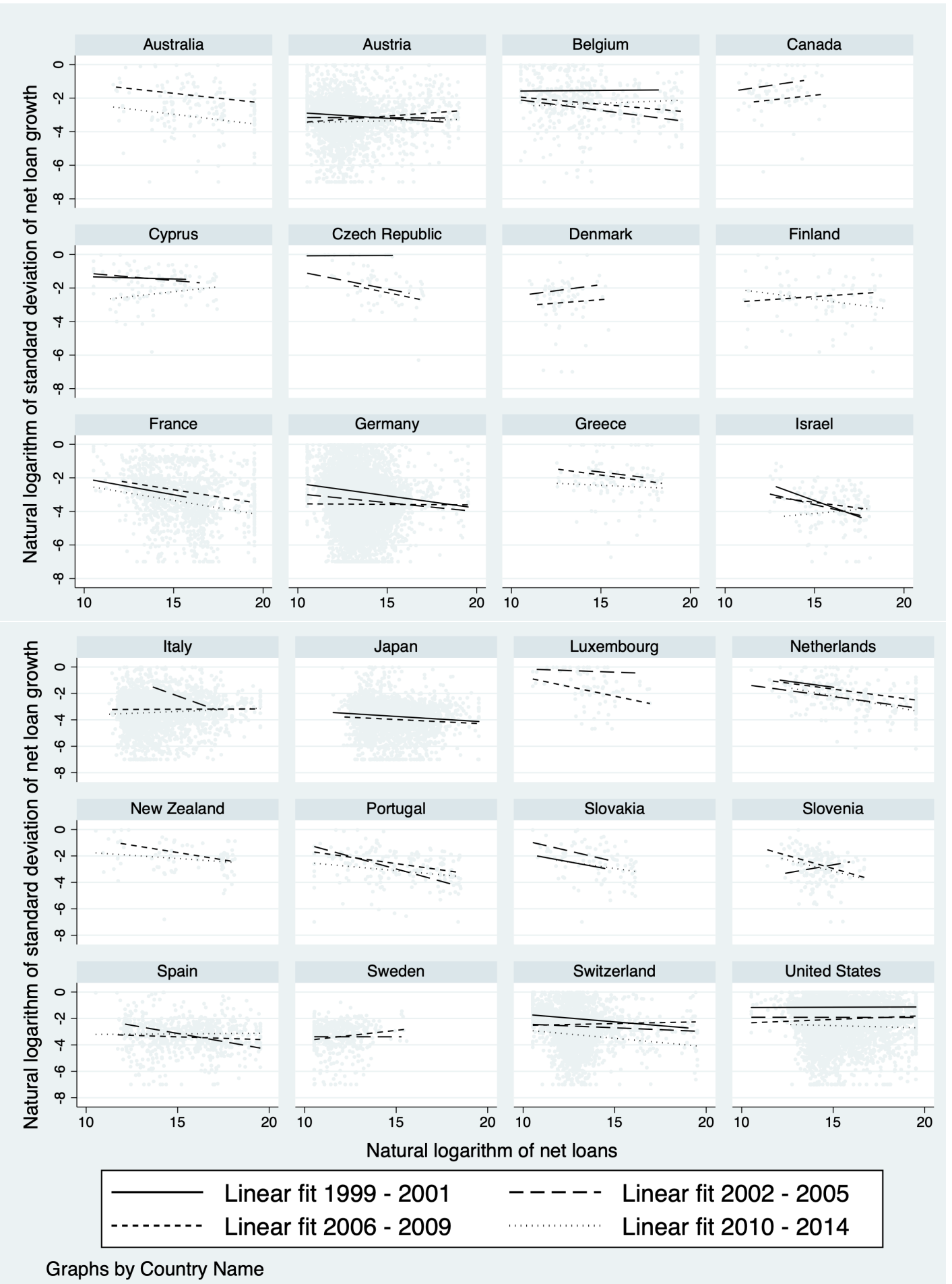

Note: This figure shows the linear fit of the linearized power law that relates loan portfolio volatility to size as defined in equation (1) for four sub-periods in each country. The slope of the fitted lines reflects the power law parameter $\alpha$. 


\section{Tables}

Table 1: Hypothetical effects of regulations on the size-volatility nexus

\begin{tabular}{lcc}
\hline Regulatory measure & Effect on nexus $\left(\theta_{1}\right)$ & Channel \\
\hline Capital regulation stringency & $+/-$ & DIV, MH \\
Bank levies & $+/-$ & DIV, MH \\
Guideline for asset diversification & - & DIV \\
Restrictions on bank activities & + & DIV \\
Bank guarantees & + & $\mathrm{MH}$ \\
Independence of supervisory authority & - & $\mathrm{MH}$ \\
Private monitoring & - & $\mathrm{MH}$ \\
\hline
\end{tabular}

Note: Information on regulatory interventions are taken from the World Bank Banking Supervision Survey, Laeven and Valencia (2012), and from Cerutti et al. (2017). For more detailed information, see Table 9 in the data appendix. DIV: diversification channel, MH: moral hazard channel.

Table 2: Summary statistics

\begin{tabular}{lrrrrr}
\hline Bank-level variables & Obs. & Mean & SD & Min & Max \\
\hline Standard deviation of net loans & 39,430 & 0.1216 & 0.1637 & 0.0009 & 0.9661 \\
Loan portfolio size in bn USD & 39,430 & 8.5467 & 33.752 & 0.0372 & 299.73 \\
Equity/total assets & 39,430 & 0.0777 & 0.0415 & 0.0138 & 0.2620 \\
Loan loss provision/net interest revenues & 39,430 & 0.1942 & 0.2062 & -0.0217 & 1.2400 \\
Non-interest expense/gross revenues & 39,430 & 0.6618 & 0.1413 & 0.2577 & 1.1915 \\
Return on average assets & 39,430 & 0.5354 & 0.7396 & -2.1200 & 1.1915 \\
Net loans/total assets & 39,430 & 0.6377 & 0.1681 & 0.0851 & 0.9339 \\
\hline Country-level variables & & & & & \\
\hline Capital regulation stringency & 39,430 & 6.3370 & 1.2693 & 2.0000 & 9.0000 \\
Levy/tax & 39,430 & 0.0470 & 0.2117 & 0.0000 & 1.0000 \\
Diversification guidelines & 39,430 & 0.3759 & 0.4844 & 0.0000 & 1.0000 \\
Activities restrictions & 39,430 & 8.7541 & 1.8039 & 4.0000 & 13.000 \\
Bank guarantees & 39,430 & 0.3547 & 0.4784 & 0.0000 & 1.0000 \\
Independence & 39,430 & 1.6199 & 0.6342 & 0.0000 & 3.0000 \\
Private monitoring & 39,430 & 8.4929 & 1.4160 & 5.0000 & 11.000 \\
\hline
\end{tabular}

Note: This table presents summary statistics based on the pre-processed panel used for the baseline estimations in Table 5 . 


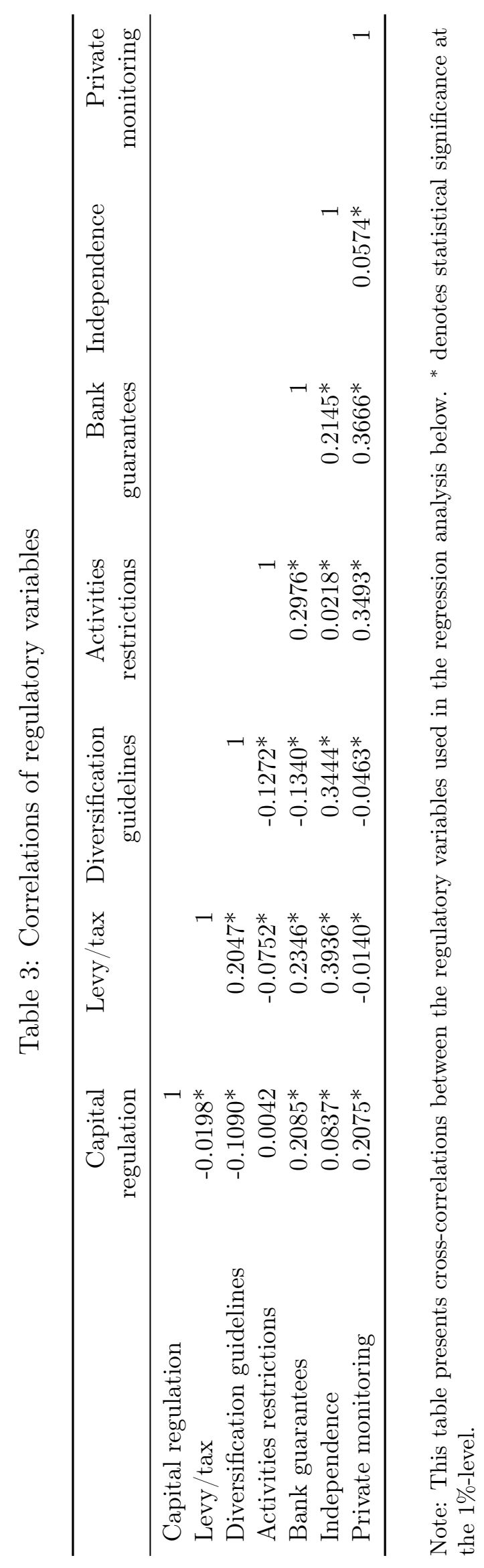


Table 4: Countries included in the panel

\begin{tabular}{lrr}
\hline Country & Observations & \% \\
\hline Australia & 173 & 0.44 \\
Austria & 2,566 & 6.51 \\
Belgium & 420 & 1.07 \\
Canada & 66 & 0.17 \\
Cyprus & 107 & 0.27 \\
Czech Republic & 61 & 0.15 \\
Denmark & 70 & 0.18 \\
Finland & 81 & 0.21 \\
France & 1,368 & 3.47 \\
Germany & 11,245 & 28.52 \\
Greece & 118 & 0.30 \\
Israel & 147 & 0.37 \\
Italy & 3,462 & 8.78 \\
Japan & 2,835 & 7.19 \\
Luxembourg & 75 & 0.19 \\
Netherlands & 234 & 0.59 \\
New Zealand & 87 & 0.22 \\
Portugal & 187 & 0.47 \\
Slovakia & 94 & 0.24 \\
Slovenia & 173 & 0.44 \\
Spain & 718 & 1.82 \\
Sweden & 405 & 1.03 \\
Switzerland & 3,441 & 8.73 \\
United States & 11,297 & 28.65 \\
\hline Total & $\mathbf{3 9}, \mathbf{4 3 0}$ & $\mathbf{1 0 0}$ \\
\hline
\end{tabular}

Note: This table presents the total number of observations as well as the share by country of our baseline sample. 


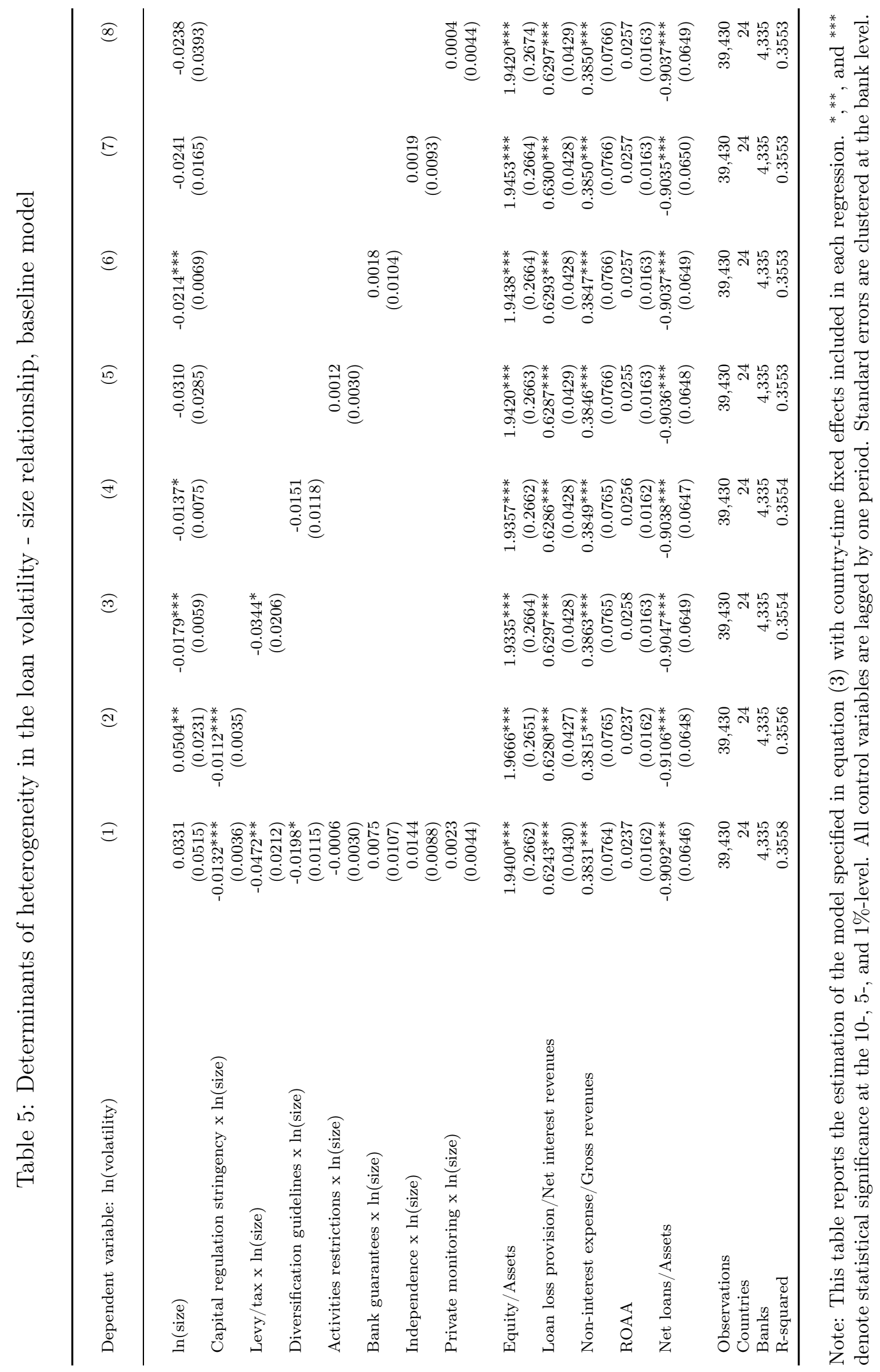




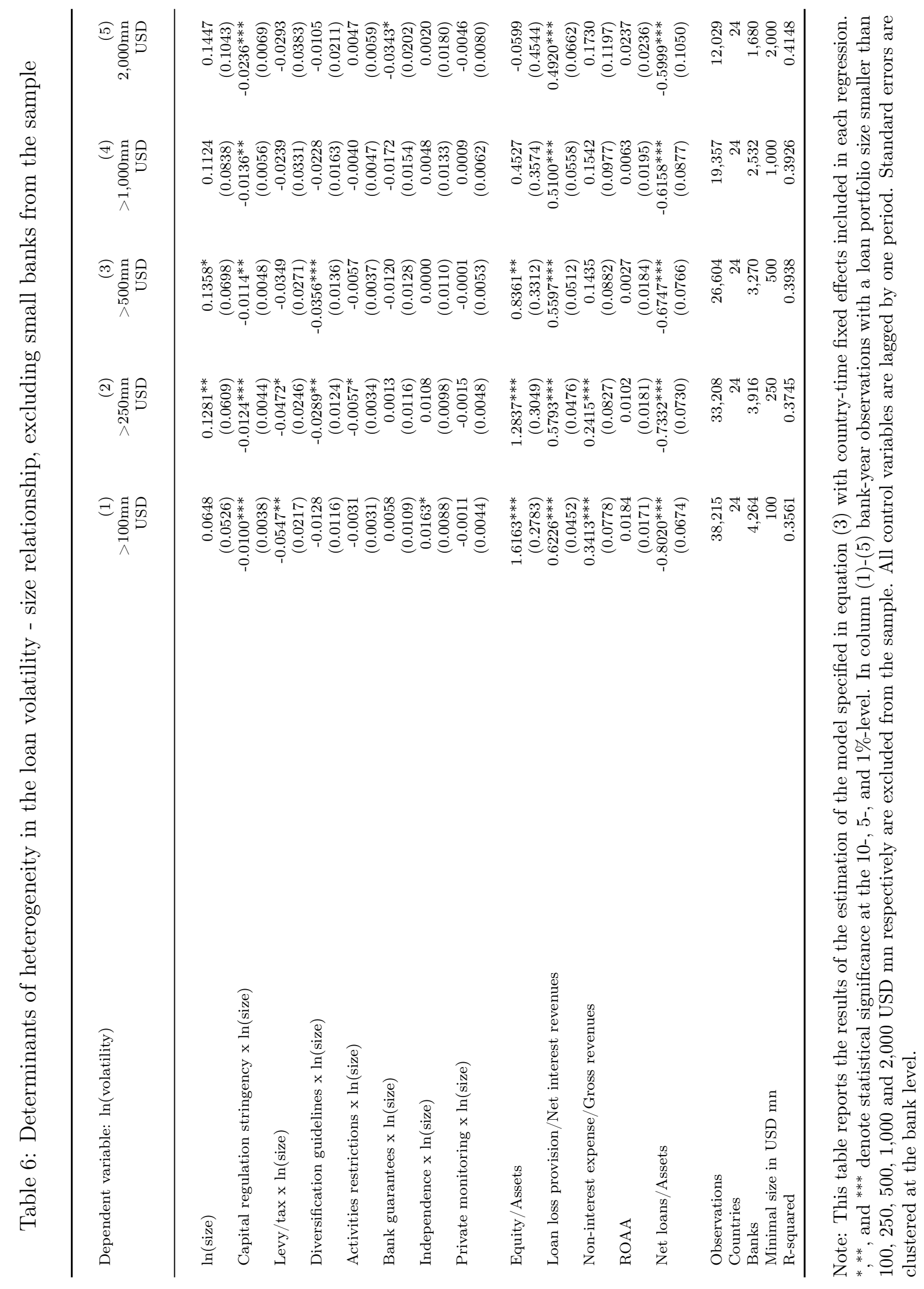




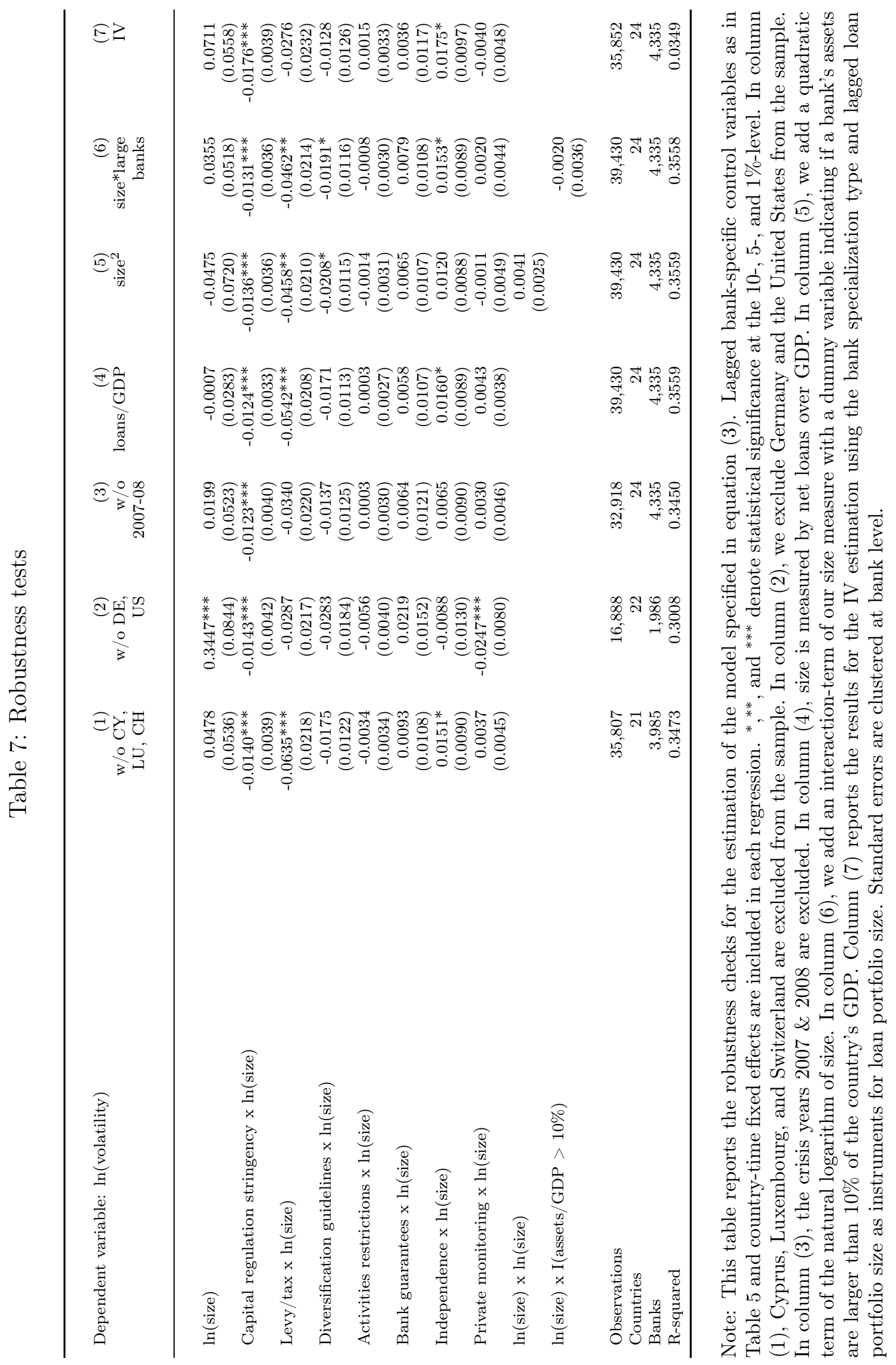




\section{Data Appendix}

Table 8: Definitions of bank-specific control variables

\begin{tabular}{|c|c|c|c|c|}
\hline Characteristic & Control & Bankscope Definition & $+/-*$ & Used by \\
\hline Capital adequacy & $\begin{array}{l}\text { Equity/ Total } \\
\text { assets }\end{array}$ & $\begin{array}{l}\text { As equity is a cushion against asset malfunction, } \\
\text { this ratio measures the amount of protection af- } \\
\text { forded to the bank by the equity they invested } \\
\text { in it. The higher this figure the more protection } \\
\text { there is. }\end{array}$ & $-/+$ & $\begin{array}{l}\text { Bhagat et al. (2015), } \\
\text { Houston et al. (2010) }\end{array}$ \\
\hline Asset quality & $\begin{array}{l}\text { Loan loss pro- } \\
\text { vision/ Net in- } \\
\text { terest revenues }\end{array}$ & $\begin{array}{l}\text { This is the relationship between provisions in } \\
\text { the profit and loss account and the interest in- } \\
\text { come over the same period. Ideally, this ra- } \\
\text { tio should be as low as possible and, in a well- } \\
\text { run bank, if the lending book is higher risk this } \\
\text { should be reflected by higher interest margins. } \\
\text { If the ratio deteriorates, this means that risk is } \\
\text { not being properly remunerated by margins. }\end{array}$ & + & Beck et al. (2013) \\
\hline $\begin{array}{l}\text { Management ca- } \\
\text { pability }\end{array}$ & $\begin{array}{l}\text { Non-interest } \\
\text { expense/ Gross } \\
\text { revenues }\end{array}$ & $\begin{array}{l}\text { This is an indicator of efficiency, measuring the } \\
\text { overheads or costs of running the bank, the ma- } \\
\text { jor element of which is normally salaries, as } \\
\text { a percentage of net income before impairment } \\
\text { charges. The lower the better. }\end{array}$ & + & Agoraki et al. (2011) \\
\hline Earnings & $\begin{array}{l}\text { Return on } \\
\text { average assets }\end{array}$ & $\begin{array}{l}\text { This is perhaps the most important single ra- } \\
\text { tio in comparing the efficiency and operational } \\
\text { performance of banks as it looks at the returns } \\
\text { generated from the assets financed by the bank. }\end{array}$ & - & $\begin{array}{l}\text { Bhagat et al. (2015), } \\
\text { Houston et al. } \\
(2010), \\
\text { Jiménez et al. (2013) }\end{array}$ \\
\hline Liquidity & $\begin{array}{l}\text { Net loans/ To- } \\
\text { tal assets }\end{array}$ & $\begin{array}{l}\text { This liquidity ratio indicates what percentage } \\
\text { of the assets of the bank are tied up in loans. } \\
\text { The higher this ratio the less liquid the bank } \\
\text { will be. }\end{array}$ & - & $\begin{array}{l}\text { Beck et al. (2013), } \\
\text { Laeven et al. (2016) }\end{array}$ \\
\hline
\end{tabular}

Note: * expected effect on loan portfolio volatility. 
Table 9: Details on regulations

\begin{tabular}{|c|c|c|c|c|c|}
\hline Regulation & Description & Range & $\begin{array}{l}\text { Effect on } \\
\text { nexus }\end{array}$ & $\begin{array}{l}\text { Constant } \\
\text { periods }\end{array}$ & Source \\
\hline $\begin{array}{l}\text { Capital regula- } \\
\text { tion stringency }\end{array}$ & $\begin{array}{l}\text { Measures whether capital requirements } \\
\text { reflect certain risk elements \& certain } \\
\text { market value losses are deducted be- } \\
\text { fore determining minimum capital ade- } \\
\text { quacy, whether certain funds may be } \\
\text { used to initially capitalize a bank and } \\
\text { if they are officially verified; a hig- } \\
\text { her number indicates greater stringency } \\
\text { with respect to capital regulation. }\end{array}$ & $\{0, \ldots, 10\}$ & $+/-$ & $\begin{array}{l}{\left[\begin{array}{lll}\mathbf{9 9} & 00 & 01\end{array}\right],} \\
{\left[\begin{array}{llll}\mathbf{0 2} & 03 & 04 & 05\end{array}\right]} \\
{\left[\begin{array}{llll}\mathbf{0 6} & 07 & 08 & 09\end{array}\right]} \\
{\left[\begin{array}{llll}10 & \mathbf{1 1} & 12 & 13 \\
14\end{array}\right]}\end{array}$ & $\begin{array}{l}\text { World } \\
\text { Bank } \\
\text { Banking } \\
\text { Supervi- } \\
\text { sion Survey }\end{array}$ \\
\hline Levy/tax & $\begin{array}{l}\text { Dummy variable, which is } 1 \text { if there is } \\
\text { a levy or tax imposed on the income of } \\
\text { financial institutions and } 0 \text { otherwise. }\end{array}$ & $\{1,0\}$ & + & $\begin{array}{l}{\left[\begin{array}{ll}99 & \mathbf{0 0}\end{array},[\mathbf{0 1}]\right.} \\
\ldots,[\mathbf{1 4}]\end{array}$ & $\begin{array}{l}\text { Macro- } \\
\text { prudential } \\
\text { Policies } \\
\text { Database, } \\
\text { Dever- } \\
\text { eux et al. } \\
(2015)\end{array}$ \\
\hline $\begin{array}{l}\text { Diversification } \\
\text { guidelines }\end{array}$ & $\begin{array}{l}\text { Indicates whether there are explicit, } \\
\text { verifiable, and quantifiable guidelines } \\
\text { for asset diversification; guidelines may } \\
\text { prescribe loan exposure limits to indi- } \\
\text { vidual borrowers as well as to regio- } \\
\text { nal, geographical, and sectoral exposu- } \\
\text { res; the dummy variable being } 1 \text { indi- } \\
\text { cates more diversification. }\end{array}$ & $\{1,0\}$ & - & $\begin{array}{l}{\left[\begin{array}{lll}\mathbf{9 9} & 00 & 01\end{array}\right],} \\
{\left[\begin{array}{llll}\mathbf{0 2} & 03 & 04 & 05\end{array}\right],} \\
{\left[\begin{array}{llll}\mathbf{0 6} & 07 & 08 & 09\end{array}\right]} \\
{\left[\begin{array}{llll}10 & \mathbf{1 1} & 12 & 13 \\
14\end{array}\right]}\end{array}$ & $\begin{array}{l}\text { World } \\
\text { Bank } \\
\text { Banking } \\
\text { Supervi- } \\
\text { sion Survey }\end{array}$ \\
\hline $\begin{array}{l}\text { Restrictions on } \\
\text { bank activities }\end{array}$ & $\begin{array}{l}\text { Measures the extent to which a bank } \\
\text { can engage in securities, insurance, and } \\
\text { real estate activities as well as own non- } \\
\text { financial firms; a higher number indica- } \\
\text { tes greater restrictiveness. }\end{array}$ & $\{4, \ldots, 16\}$ & + & $\begin{array}{l}{\left[\begin{array}{lll}\mathbf{9 9} & 00 & 01\end{array}\right],} \\
{\left[\begin{array}{llll}\mathbf{0 2} & 03 & 04 & 05\end{array}\right],} \\
{\left[\begin{array}{llll}\mathbf{0 6} & 07 & 08 & 09\end{array}\right]} \\
{\left[\begin{array}{llll}10 & \mathbf{1 1} & 12 & 13 \\
14\end{array}\right]}\end{array}$ & $\begin{array}{l}\text { World } \\
\text { Bank } \\
\text { Banking } \\
\text { Supervi- } \\
\text { sion Survey }\end{array}$ \\
\hline Bank guarantees & $\begin{array}{l}\text { Dummy variable, which is } 1 \text { if bank } \\
\text { guarantees were in place and } 0 \text { other- } \\
\text { wise. }\end{array}$ & $\{1,0\}$ & + & $\begin{array}{l}{[\mathbf{9 9}], \ldots,[\mathbf{1 0}],} \\
{\left[\begin{array}{llll}\mathbf{1 1} & 12 & 13 & 14\end{array}\right]}\end{array}$ & $\begin{array}{l}\text { Systemic } \\
\text { Crises } \\
\text { Database }\end{array}$ \\
\hline $\begin{array}{l}\text { Independence of } \\
\text { the supervisory } \\
\text { authority }\end{array}$ & $\begin{array}{l}\text { Measures the degree to which the } \\
\text { supervisory authority is independent } \\
\text { from political influence, protected by } \\
\text { the legal system from the banking in- } \\
\text { dustry, able to make decisions inde- } \\
\text { pendently of political considerations; a } \\
\text { higher value indicates greater indepen- } \\
\text { dence. }\end{array}$ & $\{0, \ldots, 3\}$ & - & $\begin{array}{l}{\left[\begin{array}{lll}\mathbf{9 9} & 00 & 01\end{array}\right],} \\
{\left[\begin{array}{llll}\mathbf{0 2} & 03 & 04 & 05\end{array}\right]} \\
{\left[\begin{array}{llll}\mathbf{0 6} & 07 & 08 & 09\end{array}\right]} \\
{\left[\begin{array}{llll}10 & \mathbf{1 1} & 12 & 13 \\
14\end{array}\right.}\end{array}$ & $\begin{array}{l}\text { World } \\
\text { Bank } \\
\text { Banking } \\
\text { Supervi- } \\
\text { sion Survey }\end{array}$ \\
\hline $\begin{array}{l}\text { Private monito- } \\
\text { ring }\end{array}$ & $\begin{array}{l}\text { Measures the extent to which subordi- } \\
\text { nated debt qualifies as Tier } 1 \text { and Tier } 2 \\
\text { capital, whether off-balance sheet items } \\
\text { must be disclosed and regulators are re- } \\
\text { quired to undertake public formal en- } \\
\text { forcement actions; a higher value indi- } \\
\text { cates greater private monitoring power. }\end{array}$ & $\{0, \ldots, 12\}$ & - & $\begin{array}{l}{\left[\begin{array}{lll}\mathbf{9 9} & 00 & 01\end{array}\right],} \\
{\left[\begin{array}{llll}\mathbf{0 2} & 03 & 04 & 05\end{array}\right]} \\
{\left[\begin{array}{llll}\mathbf{0 6} & 07 & 08 & 09\end{array}\right]} \\
{\left[\begin{array}{llll}10 & \mathbf{1 1} & 12 & 13 \\
14\end{array}\right.}\end{array}$ & $\begin{array}{l}\text { World } \\
\text { Bank } \\
\text { Banking } \\
\text { Supervi- } \\
\text { sion Survey }\end{array}$ \\
\hline
\end{tabular}

